\section{Utilization of aluminium dross as asphalt filler}

ZoLTÁN SOÓS - Department of Highway and Railway Engineering, Budapest University of Technology and Economics - soos.zoltan.epito@gmail.com

RóBERT GÉBER - Institute of Ceramics and Polymer Engineering, University of Miskolc

CsabA TÓTH - Department of Highway and Railway Engineering, Budapest University of Technology and Economics

ZsuZSANNA IGAZVÖLGYI - Department of Highway and Railway Engineering, Budapest University of Technology and Economics

BELLA UDVARDI - Institute of Ceramics and Polymer Engineering, University of Miskolc

Érkezett: 2017. 10. 15. - Received: 15. 10. 2017. - https://doi.org/10.14382/epitoanyag-jsbcm.2017.15

\section{Abstract}

Asphalt industry finds itself battling ongoing economic difficulties and an urge to achieve a more sustainable development and growth. It means constant searching is needed for alternative materials and possibilities to use recycled and processed waste materials in asphalt mixes as long as an expected level of performance and durability is provided.

Aluminium dross is a recyclable by-product of the casting process of melted aluminium. In this study an attempt was made to reveal the potentials of using aluminium dross as filler for asphalt wearing course mixes.

During the research, filler fractions $(\mathrm{d}<0.063 \mathrm{~mm})$ were prepared by milling and microstructural tests were conducted both on the alternative and control filler for a better understanding of the materials and their composition. The effect of replacing limestone filler with aluminium dross filler on the performance of asphalt mixes was analysed by performance-based and performance related asphalt mechanical tests according to common standards. In the paper, the properties of fillers and various mechanical test results are presented and by interpreting the tests and results final conclusions are presented regarding the use of aluminium dross as filler in asphalt mixes. Keywords: asphalt, aluminium dross, filler, rheology, stiffness

Kulcsszavak: aszfalt, alumínium salak, töltôanyag, reológia, merevség

\section{Introduction}

Handling, storage and wrecking of several waste material (construction and demolition waste, oil-drill cuttings, industrial by-products, etc.) is produced year by year which causes significant problems all over the world. To avoid these materials to damage the environment, they have to be recycled. Besides storing them on landfills, another way is the industrial utilization which may forward the reduction of yielding the available raw materials. A possible field of application of waste is building industry.

Utilization of different waste materials in concrete has been the subject of several research work. Aliabdo et al. [1] have done a comparative research work on the utilization of crushed clay brick in concrete. Kim [2] dealt with the application of waste concrete powder in self-consolidating concrete and its attribute characteristics. An extensive literature $[3,4,5,6,7]$ is dealing with the application of concrete waste as aggregate in asphalt mixtures.

Utilization of different types of slags (basic oxygen furnace slag, steel slag) $[8,9,10,11,12]$ produced during various metallurgical processes as asphalt aggregate also showed good results. Based on the above mentioned research, it can be stated that mixtures made with slags have nearly the same performance as mixtures made with regular aggregates. Besides, slag - among others - improves resistance to plastic deformation and fatigue of asphalt pavements and it also decreases failure taking place due to sensitivity against
Zoltán SoóS PhD

Obtained PhD in 2017 at Department of Highway and Railway Engineering, BME. Member of the Hungarian Scientific Association for Transport. Research topics include testing and design of asphalt pavement materials and road structures with emphasis on fatigue behaviour and service life, performance and structural design. Takes part in lecturing at the University and as Deputy Head, in the work of the Pavement Laboratory since 2015.

Róbert GÉBER PhD

PhD since 2013. Working at the Institute of Ceramics and Polymer Engineering, University of Miskolc as assistant professor. Field of interests: testing of ceramics and composite materials including asphalt pavement materials. Member of the Scientific Society of the Silicate Industry, and author or co-author of 30 scientific articles.

Csaba TÓTH PhD, MBA

Member of the Hungarian Chamber of Engineers, the Hungarian Scientific Association for Transport and the Hungarian Road Society. Worked as Head of Division at Csongrád Couty Road Administration, then ÁKMI Kht. Involved in quality control of Hungarian road developments and both national and international researches as part of the Strabag concern. Had a role in several road overlay projects as engineering expert, designer and supervisor. Currently Assistant Professor and Head of Asphalt Unit at the Pavement Laboratory. Research field includes load bearing capacity of road structures and overlay design of flexible pavements.

Zsuzsanna IGAZVÖLGYI PhD Assistant professor at the Department of Highway and Railway Engineering at BME since 2015 and member of the Pavement Laboratory since 2016. Main field of research involve asphalt materials, pavements and infrastructure design. Member of the Member of the Hungarian Scientific Association for Transport

Bella UDVARDI, BSc Graduated in 2017 as material engineer, BSc. Currently working on her MSc diploma work. 
moisture. Friction characteristics between vehicles and pavements can be improved by application of slag aggregates in wearing course and failure phenomena (rutting, cracking) can also be decreased in a great extent. By using slags, an improvement can be reached in the values of indirect tensile test, creep modulus and stripping.

Automotive casting was strengthened over the past decade in Hungary. A large amount of aluminium alloy is used during the aluminium melting process, significant amount of dross is formed due to oxidation process, which is a recyclable byproduct. This waste material is produced during melting of alumina scrap; its general composition is: $15-30 \% \mathrm{Al}_{2} \mathrm{O}_{3}, 30$ $55 \% \mathrm{NaCl}, 15-30 \% \mathrm{KCl}$ and $5-7 \%$ of metallic aluminium and other impurities (carbides, nitrides, sulphides, phosphides). Several researches were made in the scope of recycling such drosses, mainly in the field of concrete technology [13, 14, 15]. These results showed that strength of the concrete made by substituting cement by $15 \%$ aluminium dross approached strength values of conventional concrete. Besides, alumina slag can be used for producing paver blocks and refractory blocks and can also be used where conventional concrete is applied.

\section{Experimental}

\subsection{Sample preparation}

Two types of fillers were used in this research. One was the aluminium dross, the other was limestone which was used as a reference material. The required particle size of fillers $(d<0.063$ $\mathrm{mm}$ ) was obtained by sieving. Samples were then dried to weight constancy.

During the research the following tests were done on the fillers to reveal their properties. Mineralogical composition of samples was determined by X-ray powder diffraction (XRD) on a Rigaku MiniFlex II diffractometer. Particle size distribution (PSD) of the sieved material was measured by a Malvern Mastersizer X laser diffraction particle size analyzer in dry mode using air as dispersing media. Specific gravity of fillers was determined by pycnometer method according to MSZ EN 1097-7 standard. Hydrophilic coefficient was also determined by sedimentation method. Rigden Void of fillers were determined according to MSZ EN 1097-4 standard. For morphological tests Carl Zeiss EVO MA10 scanning electron microscope (SEM) was used. Specific surface area (SSA) of the powders (by BET-method) was determined by Micromeritics TriStar 3000 instrument.

\subsection{Asphalt mix tests}

The use of secondary and waste materials, slag and dross materials, to substitute certain parts of asphalt mixes is not a novelty in the past decades with a constant pursuit for a better sustainable environment, and asphalt industry [16, 17, 18]. Research has shown that the use, instead of disposal, of such byproducts may be a promising way, amongst others, having at least no negative effects on performance while solving part of some issues related to the accessibility of virgin materials $[19,20]$.

In order to test performance of asphalt mixes having nonstandard composition everyday methods as indirect tensile strength, wheel tracking, water sensitivity or fatigue may be inadequate, and require high volumes of the experimental material [21]. Furthermore as bituminous mixes have a rather complex, time and temperature behaviour, being a challenge to model and understand, multiple types of tests are required to assess performance at multiple testing conditions [22, 23, 24].

To obtain an overlook on the expected performance effect of replacing (part) of the pure limestone filler with dross simple performance test (SPT) as developed by NCHRP Project 9-19 was made on multiple temperatures, was made using a frequency sweep between $0.1 \mathrm{~Hz}-25 \mathrm{~Hz}$, due to the various possibilities to assess the data despite the simplicity of the test and the specimens [22].

To perform the preliminary tests three asphalt mix types have been made, one reference mix with $100 \%$ limestone as filler (Mix B), one mix made with 100\% aluminium dross (Mix A), and one mix using 50\% aluminium dross as filler (Mix C).

\subsection{Mix composition}

In order to assess the effect of the filler composition itself, asphalt wearing course mixes with nominal aggregate size of 11 $\mathrm{mm}$ (AC11) were made with the same aggregate composition, and the same binder type and content. Coarse aggregates have been washed and the dust loss has been compensated with fillers of the given three compositions. Thus, the total filler added was the filler by mix design and the mass of dust. Fig. 1 shows the gradation of the asphalt mixes.

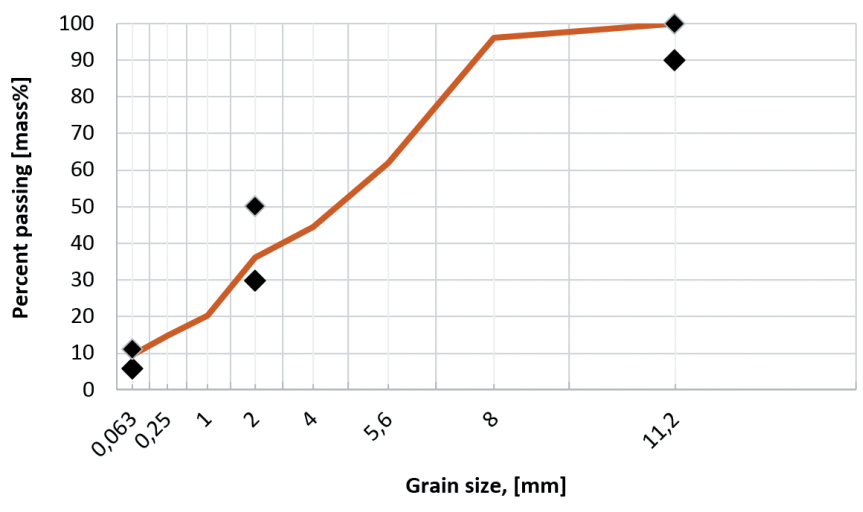

Fig. 1. Gradation of the asphalt mixes

1. ábra Aszfaltkeverékek szemeloszlása

Mixes were made using B50/70 standard bitumen with a content of $4.6 \%$. Two gyratory specimens have been made for each mix, achieving a void of $4.7-4.8 \%$, and the selected performance test has been conducted on all specimens.

\subsection{Performance tests}

Simple Performance Tests (SPT) were performed at temperatures between $0-40^{\circ} \mathrm{C}$ and frequencies between 0.1 $25 \mathrm{~Hz}$. Followed by proper conditioning intervals and resting times. Moduli and phase angle have been measured.

\section{Results and discussion}

\subsection{Filler tests}

Table 1 shows the results, which were obtained on fillers. 

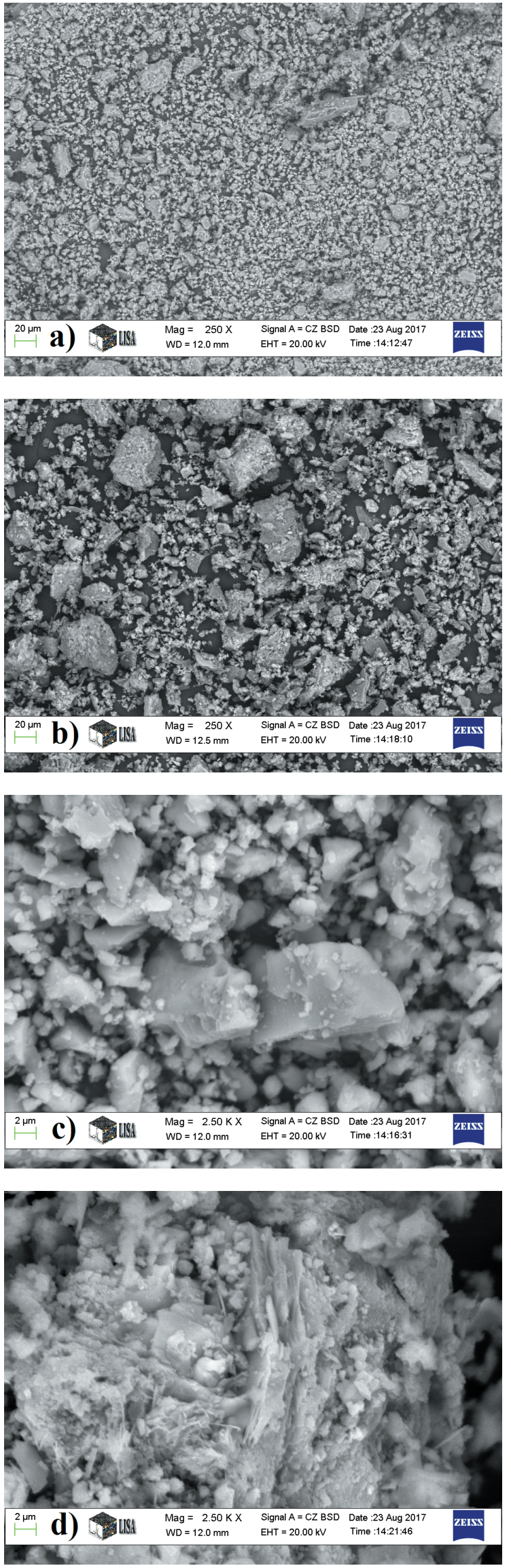

Fig. 2. Scanning electronmicrographs of fillers

2. ábra A töltöanyagok elektronmikroszkópos felvételei

\begin{tabular}{|c|c|c|c|}
\hline Parameter & Unit & Limestone & Dross \\
\hline $\begin{array}{l}\text { Specific } \\
\text { gravity, } \rho\end{array}$ & $\mathrm{g} / \mathrm{cm}^{3}$ & 2.795 & 2.904 \\
\hline $\begin{array}{l}\text { Average particle } \\
\text { size, } d_{50}\end{array}$ & $\mu \mathrm{m}$ & 13.77 & 24.96 \\
\hline $\begin{array}{l}\text { Specific surface } \\
\text { area, SSA }\end{array}$ & $\mathrm{m}^{2} / \mathrm{g}$ & 1.55 & 1.03 \\
\hline Rigden Void, $R V$ & vol\% & 47.2 & 45.7 \\
\hline $\begin{array}{l}\text { Hydrophilic } \\
\text { coefficient, } \eta\end{array}$ & - & 0.75 & 0.67 \\
\hline $\begin{array}{l}\text { Mineral } \\
\text { composition }\end{array}$ & - & $\begin{array}{c}\text { calcite }\left(\mathrm{CaCO}_{3}\right) \text {, } \\
\text { quartz }\left(\mathrm{SiO}_{2}\right) \text {, } \\
\text { dolomite } \\
\left(\mathrm{CaMg}\left(\mathrm{CO}_{3}\right)_{2}\right) \\
\text { muscovite } 2 \mathrm{M} 1 \\
\left(\mathrm{KAl}_{2}\left(\mathrm{AlSi}_{3} \mathrm{O}_{10}\right)\right. \\
\left.(\mathrm{F}, \mathrm{OH})_{2}\right)\end{array}$ & $\begin{array}{c}\text { halite }(\mathrm{NaCl}) \text {, } \\
\text { sylvite }(\mathrm{KCl}), \\
\text { potassium } \\
\text { aluminium oxide } \\
\left(\mathrm{K}_{1.5} \mathrm{Al}_{11} \mathrm{O}_{17.25}\right) \\
\text { corundum }\left(\mathrm{Al}_{2} \mathrm{O}_{3}\right)\end{array}$ \\
\hline
\end{tabular}

Table 1. Test results of fillers

1. táblázat Töltőanyagok vizsgálati eredményei

According to X-ray diffraction it can be stated that limestone build up mainly of calcite. Besides, this filler also contains dolomite, quartz and muscovite in small quantities. The main phases of dross are corundum and potassium aluminium oxide in a high quantities. Some salts, which are important components during the melting process of aluminium, like halite and sylvite have also identified during XRD tests.

The results of particle size analysis show that average particle size of limestone is smaller than aluminium dross $\left(\mathrm{d}_{50}\right.$ limestone: $13.77 \mu \mathrm{m}$ vs. $\left.d_{50 \text { dross }}: 24.96 \mu \mathrm{m}\right)$, so limestone contains much more fines than the other filler. Because of the higher quantities of fines in limestone, its specific surface is also higher. Electron micrographs (Fig. 2), taken in different magnifications also demonstrate the particle size distribution and the surficial features of fillers.

It is well observable that the surface of coarser particles of limestone is quite smooth and small calcite particles are stucked on it. Traces of open pores are not identified on the angular particles. In contrast, the surface of dross is much varied. Due to the mineral composition, smooth angular particles, plately parts and whisker-like surfaces can also be observed.

According to hydrophilic coefficient tests it can be stated that both fillers are hydrophobic which is favourable in asphalt technology.

\subsection{Performance test results}

\subsubsection{Master curves}

Master curves of viscoelastic materials are used to give a comprehensive assessment of the material stiffness for various temperatures and loading frequencies [25, 26]. Master curves can be constructed using the temperature-frequency superposition principle. Sigmoid model was used to construct the master curves of the specimens, based on Eq. (1).

$$
\log \left|E^{*}\right|=\delta+\frac{\alpha}{1+e^{\beta-\gamma \cdot \log f_{\text {red }}}}
$$

Where is the stiffness [MPa], $\alpha, \beta, \gamma, \delta$ constants, $\mathrm{f}_{\text {red }}$ reduced frequency. Required constant parameters have been iterated 
using the least squares method. Sigmoid functions obtained and the measured values are shown on Fig. 3.

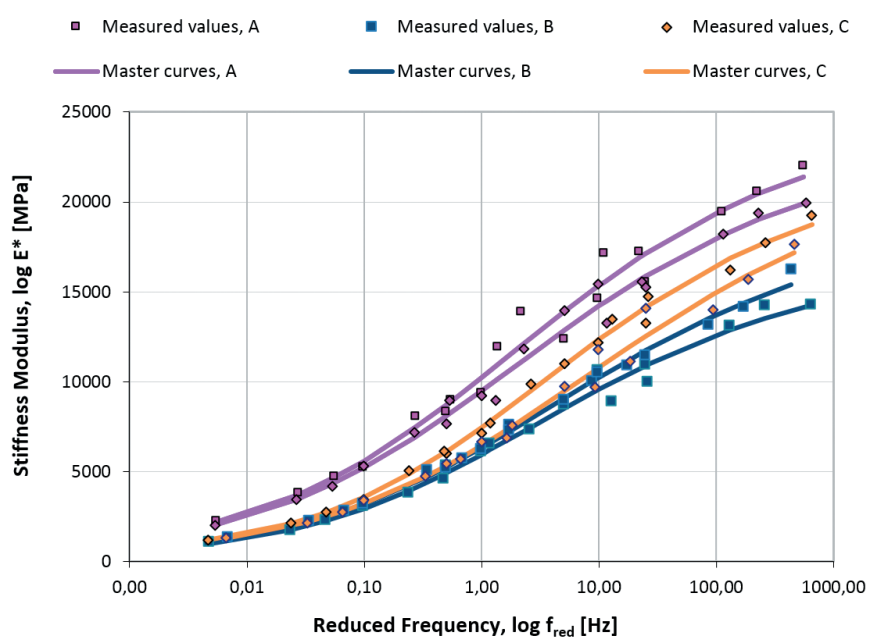

Fig. 3. Master curves of the tested specimens

3. ábra A vizsgált próbatestek mestergörbéi

As the master curves depict the mixes are stiffened by replacing limestone filler with aluminium dross. It is interesting to note that Mix A (100\% dross) is significantly stiffer throughout the frequency range but Mix C ( $50 \%$ dross) is more similar to mix B (100\% limestone) on high temperatures, and more like between the lesser two at high temperatures.

\subsubsection{Black diagrams}

Black diagrams give a good overlook on the viscoelastic properties of viscous materials such as bitumen and asphalt mixes $[27,28]$. Plotting the measured complex moduli $E^{*}$ against the phase angle $\phi$ for each measurement in the case of all three mixes results in the Black diagram shown on Fig. 4. The tool developed to assess the rheological properties of binders may be, with limitations used for asphalt mixes as well, as viscoelastic materials.

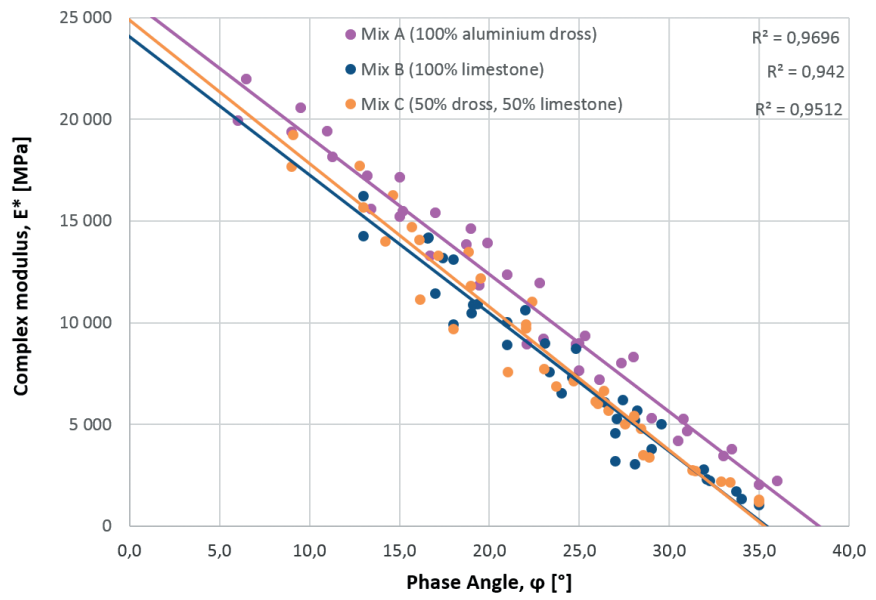

Fig. 4. Black diagrams of the tested specimens

4. ábra A vizsgált próbatestek Black diagramjai

The diagram enables the preliminary assessment of stiffness and non-linear behaviour. As the diagram shows, Mix A has higher stiffness values at given phase angles than the other two mixes, being similar at high phase angles, indicating that Mix A would perform more stiff at high temperatures and/or high frequencies. Notice that the 'return' of the curve is missing in all cases, which is normal taken into account the fact that asphalt mixes have been measured.

\subsubsection{Cole-Cole diagrams}

By using the known function of the complex modulus $\mathrm{E}^{*}$ as shown on Eq. (2), storage modulus and loss modulus $\mathrm{E}_{1}$ and $\mathrm{E}_{2}$, respectively, can be calculated according to Eq. (3) and Eq. (4).

$$
\begin{aligned}
& \left|E^{*}\right|=\frac{\left|\sigma_{0}\right|}{\left|\varepsilon_{0}\right|}=\sqrt{E_{1}^{2}+E_{2}^{2}} \\
& E_{1}=E^{*} \cdot \cos \varphi \\
& E_{2}=E^{*} \cdot \sin \varphi
\end{aligned}
$$

Where $\mathrm{E}^{*}$ is the complex modulus, $\sigma_{0}$ is the maximum stress, $\varepsilon_{0}$ is the maximum strain, $\phi$ is the phase angle $\left[{ }^{\circ}\right], \mathrm{E}_{1}$ is the storage modulus [MPa], and $\mathrm{E}_{2}$ the loss modulus [MPa].

Storage modulus represents the part of the deforming stress that is stored in the deformed material and at the end of the deformation is used to cease the deformation. Loss modulus is the part of the stress that is usually lost during a deformation in heat form. Plotting the loss modulus against the storage modulus results the Cole-Cole diagram, as shown on Fig. 5.

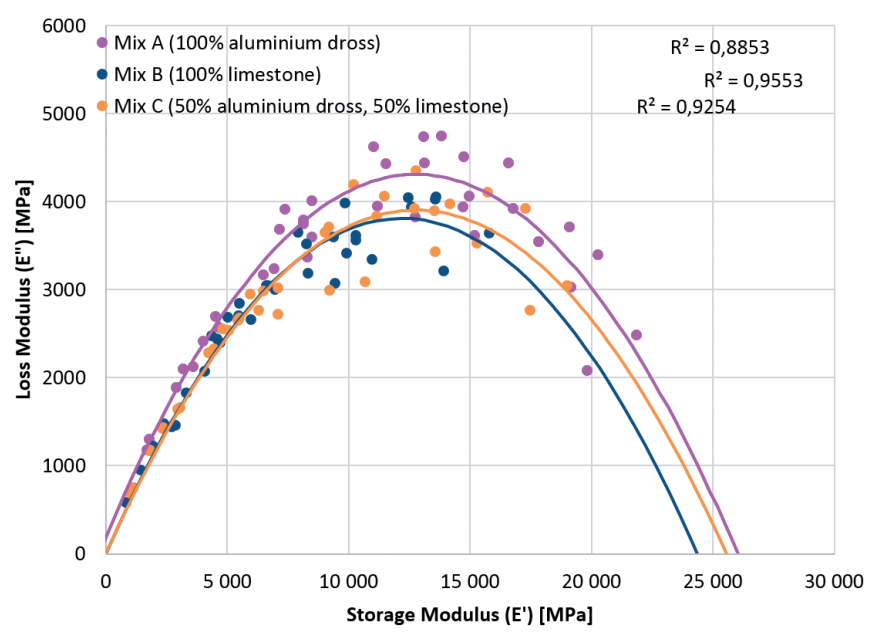

Fig. 5. Cole-Cole diagrams of the tested specimens

5. ábra A vizsgált próbatestek Cole-Cole diagramjai

The left part of the diagram indicates the mix behaviour at high temperatures, whereas the right hand side indicates the behaviour at low temperatures. Angle of given vectors pointing from zero to an arbitrary point on the graphs is called the loss angle.

The farther the intersections on the right side are, stiffer the materials are at low temperatures. As seen, the more the ratio of dross in the filler is, the stiffer the mix becomes in all temperature ranges compared to the limestone only filler. Furthermore, the stiffening effect is relatively higher on high temperatures than on low temperatures.

\section{Conclusions}

Simple Performance Test results have been conducted to preliminarily assess the effect of replacing limestone filler with 
dross on the potential performance of the resulting asphalt mix. An interesting effect which requires further research is that the stiffening effect of the limestone is higher on low temperatures (low frequencies), and lower on low temperatures.

As seen, replacing the limestone filler with dross not only stiffens the asphalt mix, but increases the phase angle as well. However, replacing only $50 \%$, i.e. only a part of the filler with dross may be a good direction for further research.

\section{Acknowledgement}

Present research is a part of GINOP -2.2.1-15-201600018 project.

The research results were presented in ic-rmm3 Conference, in Miskolc-Lillafüred, October, 2017.

\section{References}

[1] Aliabdo, A. A. - Abd-Elmoaty, M. A. - Hassan, H. H. (2014): Utilization of crushed clay brick in concrete industry. Alexandria Engineering Journal. Vol. 53, pp. 151-168, https://doi.org/10.1016/j.aej.2013.12.003

[2] Kim, Y-J. (2017): Quality properties of self-consolidating concrete mixed with waste concrete powder. Construction and Building Materials, Vol. 135, pp. 177-185, https://doi.org/10.1016/j.conbuildmat.2016.12.174

[3] Bhusal, S. - Li, X. - Wen, H. (2011): Evaluation of effects of Recycled Concrete Aggregate on volumetrics of Hot-Mix Asphalt. Transportation Research Record: Journal of the Transportation Research Board, Vol. 2205, pp. 36-39, https://doi.org/10.3141/2205-05

[4] Pasandín, A. R. - Pérez, I. (2014): Adhesion of Recycled Concrete Aggregates, demolition debris, and asphalt. Petroleum Science and Technology, Vol. 32. pp. 2584-91, http://dx.doi.org/10.1080/10916466.2013.856444

[5] Arabani, M. - Moghadas Nejad, F. - Azarhoosh, A. R. (2013): Laboratory evaluation of recycled waste concrete into asphalt mixtures. International Journal of Pavement Engineering, Vol. 14. No. 6. pp. 531-539, http://dx.doi.org/10.1080/10298436.2012.747685

[6] Paranavithana, S. - Mohajerani, A. (2006): Effects of recycled concrete aggregates on properties of asphalt concrete. Resources, Conservation and Recycling, Vol. 48. No.1.pp. 1-12, https://doi.org/10.1016/j.resconrec.2005.12.009

[7] Wong, Y. D. - Sun, D. D. - Lai, D. (2007): Value-added utilisation of recycled concrete in hot-mix asphalt. Waste Management, Vol. 27. No. 2. pp. 294-301, https://doi.org/10.1016/j.wasman.2006.02.001

[8] Yi, H. - Xu, G. - Cheng, H. - Wang, J. - Wan, Y. - Chen, H. (2012): An overview of utilization of steel slag. Procedia Environmental Sciences, Vol. 16. pp. 791-801, https://doi.org/10.1016/j.proenv.2012.10.108

[9] Chen, J. S. - Wei, S.-H. (2016): Engineering properties and performance of asphalt mixtures incorporating steel slag. Construction and Building Materials, Vol. 128. pp. 148-153, https://doi.org/10.1016/j.conbuildmat.2016.10.027

[10] Haritonovs, V. - Zaumanis, M. - Brencis, G. - Smirnovs, J. (2013): Asphalt Concrete Performance with Conventional and Waste Aggregates. International Journal of Pavement Research and Technology, Vol. 6. No. 5. pp. 505-510, http://dx.doi.org/10.6135/ijprt.org.tw/2013.6(5).505

[11] Asi, I. M. - Qasrawi, H. Y. - Shalabi, F. I. (2007): Use of steel slag aggregate in asphalt concrete mixes. Canadian Journal of Civil Engineering, Vol. 34. pp. 902-911

[12] Ézsiás, L. (2012): Kohászati salakok - a zúzottkövek megújult alternatívái az aszfaltgyártás területén. Az Aszfalt, Vol. 17. No.1 pp. 16-20

[13] Tsakiridis, P. E. (2012): Aluminium salt slag characterization and utilization - A review. Journal of Hazardous Materials, Vol. 217-218. pp. 1-10, https://doi.org/10.1016/j.jhazmat.2012.03.052

[14] Reddy, M. S. - Neeraja, D. (2016): Mechanical and durability aspects of concrete incorporating secondary aluminium slag. Resource-Efficient Technologies, Vol. 2. No. 4. pp. 225-232, https://doi.org/10.1016/j.reffit.2016.10.012
[15] Mailar, G. - Raghavendra, N. S. - Sreedhara, B. M. - Manu, D. S. Hiremath, P. - Jayakesh, K. (2016): Investigation of concrete produced using recycled aluminium dross for hot weather concreting conditions. Resource-Efficient Technologies, Vol. 2. No. 2. pp. 68-80, https://doi.org/10.1016/j.reffit.2016.06.006

[16] Aziz, M. M. A. - Hainin, M. R. - Yaacob, H. - Ali, Z. - Chang, F.-L. Adnan, A. M. (2014): Characterisation and utilisation of steel slag for the construction of roads and highways. Materials Research Innovations, Vol. 18. sup6, S6-255-S6-259, http://dx.doi.org/10.1179/1432891714Z.000000000967

[17] Krayushkina, K. - Prentkovskis, O. - Bieliatynskyi, A. - Junevičius, R. (2012): Use of steel slags in automobile road construction. Transport, Vol. 27. No. 2. pp. 129-137, http://dx.doi.org/10.3846/16484142.2012.690093

[18] Oluwasola, E. A. - Hainin, M. R. - Aziz, M. M. A. - Yaacob, H. - Warid, M. N. M. (2014): Potentials of steel slag and copper mine tailings as construction materials. Materials Research Innovations, Vol. 18. sup6, S6250-S6-254, http://dx.doi.org/10.1179/1432891714Z.000000000966

[19]Ziari, H. - Khabiri, M. M. (2007): Preventive maintenance of flexible pavement and mechanical properties of steel slag asphalt. Journal of Environmental Engineering and Landscape Management, Vol.15. No.3. pp. 188-192, http://dx.doi.org/10.1080/16486897.2007.9636928

[20] Pasetto, M. - Baldo, N. (2012): Laboratory investigation on foamed bitumen bound mixtures made with steel slag, foundry sand, bottom ash and reclaimed asphalt pavement. Road Materials and Pavement Design, Vol. 13. No. 4. pp. 691-712, http://dx.doi.org/10.1080/14680629.2012.742629

[21] Mangiafico, S. - Di Benedetto, H. - Sauzéat, C. - Olard, F. - Pouget, S. Planque, L. (2013): Influence of reclaimed asphalt pavement content on complex modulus of asphalt binder blends and corresponding mixes: experimental results and modelling. Road Materials and Pavement Design, Vol. 14:sup1, pp. 132-148, http://dx.doi.org/10.1080/14680629.2013.774751

[22] Di Benedetto, H. - Olard, F. - Sauzéat, C. - Delaporte, B. (2004): Linear viscoelastic behaviour of bituminous materials: From binders to mixes. Road Materials and Pavement Design, Vol. 5. sup1, pp. 163-202, http://dx.doi.org/10.1080/14680629.2004.9689992

[23] Olard, F. - Di Benedetto, H. (2003): General “2S2P1D " Model and Relation Between the Linear Viscoelastic Behaviours of Bituminous Binders and Mixes. Road Materials and Pavement Design, Vol. 4. No. 2. pp. 185-224, http://dx.doi.org/10.1080/14680629.2003.9689946

[24] Delaporte, B. - Di Benedetto, H. - Chaverot, P. - Gauthier, G. (2009): Linear Viscoelastic Properties of Bituminous Materials Including New Products Made with Ultrafine Particles. Road Materials and Pavement Design, Vol. 10. No. 1, pp. 7-38, http://dx.doi.org/10.1080/14680629.2009.9690180

[25] Chailleux, E. - Ramond, G. - Such, C. - de LaRoche, C. (2006): A mathematical-based master-curve construction method applied to complex modulus of bituminous materials. Road Materials and Pavement Design, Vol. 7. sup1, pp. 75-92, http://dx.doi.org/10.1080/14680629.2006.9690059

[26] Xu, Q. - Solaimanian, M. (2009): Modelling linear viscoelastic properties of asphalt concrete by the Huet-Sayegh model. International Journal of Pavement Engineering, Vol. 10. No. 6, pp. 401-422, http://dx.doi.org/10.1080/10298430802524784

[27] Biligiri, K. P. - Kaloush, K. - Uzan, J. (2010): Evaluation of asphalt mixtures' viscoelastic properties using phase angle relationships. International Journal of Pavement Engineering, Vol. 11. No.2. pp. 143-152, http://dx.doi.org/10.1080/10298430903033354

[28] Airey, G. D. (2002): Use of Black Diagrams to Identify Inconsistencies in Rheological Data, Road Materials and Pavement Design, Vol. 3. No. 4. pp. 403-424, http://dx.doi.org/10.1080/14680629.2002.9689933

Ref.:

Soós, Zoltán - Géber, Róbert - Tóth, Csaba - Igazvölgyi, Zsuzsanna - Udvardi, Bella: Utilization of aluminium dross as asphalt filler Építöanyag - Journal of Silicate Based and Composite Materials, Vol. 69, No. 3 (2017), 89-93. p. https://doi.org/10.14382/epitoanyag-jsbcm.2017.15 